\title{
Notable altitudinal range expansion of Lontra longicaudis (Carnivora: Mustelidae) in Colombian Paramos
}

\author{
Gabriel Patricio Andrade-Ponce ${ }^{1,2^{*}}$ and Teddy Angarita-Sierra ${ }^{1,2}$ \\ ${ }^{1}$ Yoluka ONG, Fundación de investigación en la biodiversidad y conservación, Carrera. 24 No. 51-81 Piso 3. Bogotá, 111311250, \\ Colombia. Email: gpandradep@unal.edu.co (GPAP), teddy.angarita@yoluka.org.co (TAS). \\ ${ }^{2}$ Corporación Autónoma Regional de Chivor CORPOCHIVOR. Carrera 5 No. 10-125 Garagoa, 152860. Boyacá, Colombia \\ ${ }^{*}$ Corresponding author
}

The neotropical otter Lontra longicaudis is a carnivore that ranges from Mexico to northern of Argentina, from 0 to 3,885 $\mathrm{m}$ above the sea level. In Colombia, this mammal is considered a research priority due the poor information about its distribution and basic ecology. The aim of this note is to contribute to the knowledge of the altitudinal distribution of L. longicaudis in the Mamapacha Paramos, Boyacá, Colombia. Camera trap fieldwork was carried out from November $18^{\text {th }}$ to December $7^{\text {th }}$ of 2015 in the department of Boyacá on the Cordillera Oriental, Colombia. Additionally, we reviewed preserved specimens and historical records of sightings above $2000 \mathrm{~m}$ in several scientific publications on L. longicaudis. Of the 275 images of wildlife, four images corresponded to L. longicaudis at the Mundo Nuevo lagoon, municipality of Chinavita $(3,110 \mathrm{~m}$ above sea level). After the literature and museum specimens review, we found that there were no records of $L$. longicaudis in Colombia that exceeded 3,000 $\mathrm{m}$ above sea level. Therefore, our record represents a notable altitudinal range expansion of $L$. longicaudis and a new altitudinal level record for the species in Colombia. This record can be a consequence of the abundant food supply provided by the Rainbow trout (Oncorhynchus mykiss). Due to the competition between otters and local people by the trout, it is necessary to implement management plans of fish resources in order to mitigate human-otter conflict and to ensure the population viability at Mundo Nuevo Lagoon.

La nutria neotropical Lontra longicaudis es un carnívoro, que se distribuye desde México hasta el norte del Argentina, entre 0 y 3,885 m sobre el nivel del mar. En Colombia la especie es considerada como prioridad de investigación debido al escaso conocimiento sobre ecología y distribución. Con el fin de contribuir al conocimiento sobre L. longicaudis en Colombia, esta nota presenta un nuevo registro altitudinal de la especie para el Páramo de Mamapacha en Boyacá, Colombia. Se realizó un estudio de fototrampeo entre el 18 de Noviembre al 7 de Diciembre del 2015 en el departamento de Boyacá en la Cordillera Oriental en Colombia. Adicionalmente, se realizó una búsqueda de especímenes preservados y registros en publicaciones científicas de L. longicaudis, considerando registros por encima de los 2,000 m sobre el nivel del mar. De un total de 275 imágenes de fauna obtenidas, se registraron cuatro de L. longicaudis para la Laguna de Mundo nuevo en el municipio de Chinvita a 3,110 m sobre el nivel del mar. Los registros encontrados en la revisión de literatura y ejemplares de museos, no superan los 3,000 $\mathrm{m}$ de altitud y en su mayoría proceden de la cordillera occidental, lo que confirma que nuestro registro representa una expansión en la distribución altitudinal y el registro más alto para la especie en Colombia. Este registro puede deberse a la abundante fuente de alimento que representa la Trucha Arcoiris (Oncorhynchus mykiss). Debido a que la trucha es un recurso que genera competencia directa entre la nutria y la población humana es necesario implementar planes de manejo del recurso pesquero con el fin de mitigar el conflicto nutria-humano y asegurar la viabilidad poblacional de la especie en el área.

Key words: Boyacá; distribution; neotropical otter; Paramo; rainbow trout

(C) 2017 Asociación Mexicana de Mastozoología, www.mastozoologiamexicana.org

\section{Introduction}

The Neotropical otter or "perro de agua" Lontra longicaudis is a carnivore of the Mustelidae family. As well as its congeners, L. longicaudis is an opportunistic predator that consumes fish (its main diet component), crustaceans, mollusks, birds, reptiles, small mammals and insects (Helder and Ker de Andrade 1997). It ranges from northern Mexico to northern Argentina in the province of Buenos Aires, with altitudinal distribution between 0 and 3,885 $\mathrm{m}$ above the sea level (Emmons and Feer 1997; Castro-Revelo and Zapata-Ríos 2001). However, its altitudinal range of preference is between 300 to $1,700 \mathrm{~m}$ (Larivière 1999). L. Iongicaudis is the most common otter in Colombia, where it inhabits the evergreen forest, rain forest and savannas associated to fresh water ecosystems (Larivière 1999; CalderónCapote et al. 2015). The Neotropical otter has low tolerance to transformed habitats. However, Trujillo and Arcila (2006) reported the presence of $L$. longicaudis on rivers with highly anthropic disturbances. Most of the published studies in Colombia have been carried out in the trans-Andean region. The most common topics for these studies include habitat use and diet (Mayor-Victoria and Botero-Botero 2010a, $\underline{b}$ ), trophic ecology of some populations that occur at Cauca and Quindio departments (Restrepo and Botero-Botero 2012), and range expansion at Putumayo (Noguera-Urbano and Montenegro-Muñoz 2011). Also, several records of $L$. longicaudis have been mentioned in regional and national mammal lists, which are based on personal observations, museum specimens records and literature compilations (see, Ferrer-Pérez et al. 2009; Ramírez-Chaves and NogueraUrbano 2010; Solari et al. 2013). Nevertheless, large areas of Colombia are lacking intensive sampling, especially the Andean highlands, and particularly the Paramos of the Cordillera Oriental. Therefore, L. longicaudis is considered 
a research priority due the poor information about its presence and abundance in the country (González-Maya et al. 2011). The aim of this paper is to gain insights on the altitudinal distribution of L. longicaudis in the Colombian Paramos of Boyacá, Colombia.

\section{Materials and Methods}

Fieldwork was carried out in the municipalities of Chinavita, Garagoa and Viracachá, department of Boyacá on the eastern slopes of the Cordillera Oriental. The sampling stations were located in Andean forest, Paramo and the ecotone between these ecosystems. Surveys were conducted between November $18^{\text {th }}$ to December $7^{\text {th }}$ of 2015 , using 12 camera-traps (four ScoutGuard SG550V and eight Bushnell 8MP Trophy Cam Standard). Each camera-trap was considered as a track sampling unit. The cameras were placed at $50 \mathrm{~cm}$ of the floor, near places with animal trails, traces, feeding places, refuges or ecotones between the Paramo and the Andean forest. The sampling effort was of 4,320 $\mathrm{h}$ of camera-recording, and each sampling station was baited at the first day of the survey during eight days with $160 \mathrm{~g}$ of sardines. Additionally, for comparative purposes, preserved specimens housed in Colección de Mamíferos Alberto Cadena García, Instituto de Ciencias Naturales of Universidad Nacional de Colombia (ICN) were examined. Also, historical records of $L$. longicaudis in scientific publications and museums were consulted, with emphasis on record sightings above $2,000 \mathrm{~m}$.

\section{Results}

A total of 275 images of wildlife were recorded, of which four pictures were of $L$. longicaudis. All records came from the station Mundo Nuevo Lagoon at the municipality of Chinavita $(3,110 \mathrm{~m}$; Figure 1$)$. These camera traps were placed over the edge of the Mundo Nuevo lagoon which is surrounded by shrubbery vegetation and frailejones (Espeletia spp.). The first and second images were taken on November 27 at 20:03 and 20:17 respectively. These pictures show one specimen of $L$. longicaudis approaching the bait. The third and fourth images were taken on November 28 at 06:57 and 09:03 respectively. In these occasions the pictures show one specimen approaching the camera-trap. Features such as sex and age cannot be distinguished from the individuals photographed (Figure 2). These images were taken in areas where otter scats and fish remains were found.

Rojas-Diaz et al. (2012) reported the presence of L. Iongicaudis at 3,000 $\mathrm{m}$ at both slopes of the Cordillera Occidental. However, that record was not confirmed due that it lacks the specific locality and collection number. Only seven specimen sightings at $2,000 \mathrm{~m}$ or above were found on the literature and museum records (Table 1). The highest altitude reported was 2,700 m (Ramírez-Chaves and Noguera-Urbano 2010), which confirms that our record represents an altitudinal range expansion of $L$. longicaudis as well as the maximum altitude recorded for the species in Colombia.
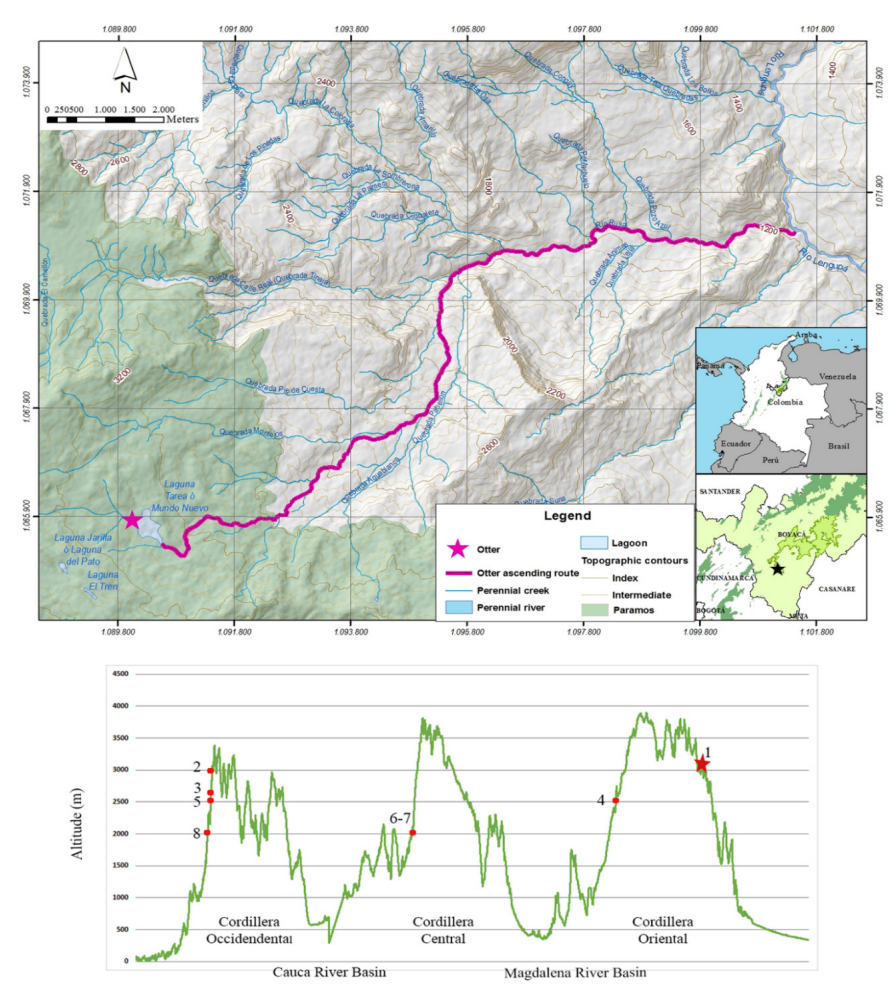

Figure 1. Record of Neotropical otter at Chinavita Municipality that extends their altitudinal range. Possible otter ascending route with the altitudinal profile of records above 2,000 $\mathrm{m}$ in Colombia based on our records and those from the literature and preserved specimens. 1. This study; 2. Rojas-díaz et al. 2012; 3. Ramírez-Chaves and Noguera-Urbano 2010; 4. FMNH 146397; 5. FMNH 8848; 6. Mayor-Victoria and Botero-Botero 2010 a; 7. Mayor-Victoria and Botero-Botero 2010 b; 8. Corantioquia 8110002317-09. Cordillera Occidental cut west to east over south of Cauca department with 135 degrees. Cordillera Central cut west to east over Valle del Cauca through south Quindío Department, with 138 degrees. Cordillera Oriental cut west to east over Tolima department to North of Meta department.

\section{Discussion}

The niche partitioning theory states that the presence of carnivores is associated directly with their prey abundance and presence (Sunquist and Sunquist 1989). The altitudinal range expansion of $L$. longicaudis from Mamapacha's Paramo at 3,110 m might supports this hypothesis. Commonly, this species inhabits riverine ecosystems between 0 to $1,700 \mathrm{~m}$ that provide a wide range of food availability (Larivière 1999). However, Guerrero-Flores et al. (2013) indicate that $L$. longicaudis is an opportunistic predator with a broad food spectrum that allows it to move outside of its preference range when abundant food supply is available. Therefore, the altitudinal range expansion of L. longicaudis can be a consequence of an abundant food supply, provided by the Rainbow trout (Oncorhynchus mykiss), an introduced species that inhabits the high mountain lagoons at Mamapacha Paramos.

The rainbow trout was introduced on Boyacá high mountain lagoons about 90 years ago with the goal to use them in artisanal and sport fisheries (Parrado-Sanabria 2012). As a result, many rainbow trout fisheries were established throughout the region of Mundo Nuevo village. Due to the generalist diet and predator characteristics of Rainbow trout, it became the dominant and most abundant species of fish on the high mountain lagoons (Martín-Torrijos et al. 
Table 1. Altitudinal records of $L$. longicaudis above $2000 \mathrm{~m}$ in Colombia.

\begin{tabular}{|c|c|c|c|c|c|c|c|}
\hline ID & Autor/Museum & Year & Departament & Municipality & Locality & coordinates & $\begin{array}{l}\text { altitude } \\
\text { (masl) }\end{array}$ \\
\hline 1 & This note & 2015 & Boyacá & Chinavita & Mundo nuevo Lagoon & $5^{\circ} 11^{\prime} 28^{\prime \prime} \mathrm{N},-73^{\circ} 15^{\prime} 55^{\prime \prime} \mathrm{W}$ & 3,110 \\
\hline 2 & Rojas-Díaz et al. & 2012 & Valle del Cauca & --- & --- & --- & 3,000 \\
\hline 3 & $\begin{array}{l}\text { Ramírez-Chaves and Noguera- } \\
\text { Urbano }\end{array}$ & 2010 & Nariño & ---- & ---- & ---- & 2,700 \\
\hline 4 & FMNH 146397 & ---- & Cundinamarca & Bogotá, D.C & Bogotá D.C. & $4^{\circ} 37^{\prime} 0^{\prime \prime} \mathrm{N},-74^{\circ} 5^{\prime} 60^{\prime \prime} \mathrm{W}$ & 2,565 \\
\hline 5 & FMNH 88481 & 1957 & Cauca & & Munchique & $2^{\circ} 31^{\prime} 60^{\prime \prime} \mathrm{N},-76^{\circ} 57^{\prime} 0^{\prime \prime} \mathrm{W}$ & 2,524 \\
\hline 6 & Mayor-Victoria and Botero-Botero & $2010 a$ & Quindío & ---- & $\begin{array}{l}\text { Near Reserva Natural La } \\
\text { montaña del Ocaso }\end{array}$ & $4^{\circ} 41^{\prime} 0^{\prime \prime} \mathrm{N},-75^{\circ} 26^{\prime} 0^{\prime \prime} \mathrm{W}$ & 2,100 \\
\hline 7 & Mayor-Victoria and Botero-Botero & $2010 b$ & Quindío & --- & Rio roble & $4^{\circ} 41^{\prime} 0^{\prime \prime}$ N. $-75^{\circ} 26^{\prime} 0^{\prime \prime} \mathrm{W}$ & 2,100 \\
\hline 8 & Corantioquia / 8110002317-09 & --- & Antioquia & Jericó & --- & $5^{\circ} 47^{\prime} 60^{\prime \prime} \mathrm{N},-75^{\circ} 47^{\prime} 24^{\prime \prime} \mathrm{W}$ & 2,000 \\
\hline
\end{tabular}

2016). Therefore, the rainbow trout is an abundant food supply that might encourage otters to move from lowlands to highlands. This pattern agrees with reports by MonroyVilchis and Mundo (2009), and Guerrero-Flores et al. (2013) who found that colonization of high mountain ecosystem in Mexico by L. longicaudis is related to the invasive species abundance, which in some cases, represents almost $100 \%$ of the otter diet. Likewise, Castro-Revelo and Zapata-Ríos (2001) have reported L. longicaudis at 3,885 $\mathrm{m}$ in Ecuador, pointing out that they found fish remains associated to the diet of the otter, however, they not specified whether they belong to native or introduced species. Whereby, more diet preference and prey abundance studies are needed in order to verify whether the altitudinal range increase of $L$. longicaudis is due to this food availability provided by the trout (Briones-Salas et al. 2013; Guerrero-Flores et al. 2013).

Additionally, based on landscape cover and the drainage connectivity. We hypothesize the possible ascending route used by L. longicaudis to reach the Mundo Nuevo Lagoon (Figure 1). First, the possible population source might have been located at Batatá dam (1,042 m). Second, the ascending route might have started from Batatá dam, through La Rusa River, through Canelo creek until reaching to Mundo Nuevo Lagoon. Moreover, a robust sampling effort must be encouraged to understand the size and distribution of $L$. longicaudis populations in the rivers and creeks of the municipalities of Chinavita, Garagoa and Viracachá.

Finally, the Mundo Nuevo Lagoon local farmers have noticed the presence of $L$. longicaudis for decades, following the introduction of rainbow trout and the establishment of trout fisheries in the area. Also, they suggest that the otter
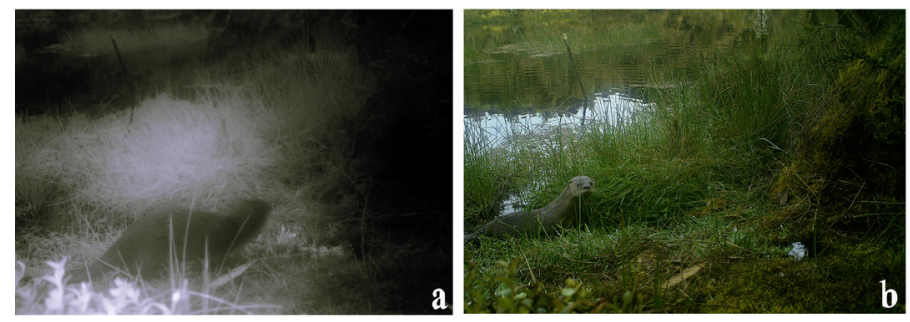

Figure 2. Records of $L$. longicaudis from municipality of Chinavita at $3,110 \mathrm{~m}$ a) Third record at 06:54, on November 28. b) Fourth record at 09:03, on November 28. population might be of about five to six individuals. But the actual number of otters that inhabits the area is unknown. The highland population of $L$. longicaudis might be threatened by local farmers because they are in direct competition for the trout, as prey for the otters and food supply or income to the farmers. Hence, Neotropical otters are considered as a pest by local fishermen, some otters have been chased and killed to diminish the otter population.

This note presents the highest altitude record of $L$. Iongicaudis in Colombia, contributing to the knowledge of neotropical otter distribution in Boyacá Paramos. Likewise, our observation suggests that altitudinal range expansion record might be associated with the prey availability that represents the introduction of Rainbow trout and the development of a trout fishery at the Paramos lagoons. However, more diet studies on the otters at Mundo Nuevo Lagoon are required to verify this hypothesis. On the other hand, conservation strategies together with environmental education are needed in order to reduce human-otter conflict.

\section{Acknowledgements}

This study was conducted under the contract No. 17315 signed by Yoluka NGO, Biodiversity and Conservation Research Foundation and the Autonomous Regional Corporation of Chivor (CORPOCHIVOR) framed in the cooperation agreement between CORPOCHIVOR and OCENSA. We thank the research team of Yoluka NGO for their assistance during the field surveys and during the preparation of the manuscript, especially to R. Morantes for technical support on GIS and J. A. Infante-Betancour, for his advice and managing support. Also, we thank F. I. Daza, for advising and reviewing this note. Finally, we give special thanks to J. J., Buitrago, and $\mathrm{H}$. Montañez for their fieldwork collaboration and their goodwill.

\section{Literature cited}

Briones-Salas, M., M. A. Peralta-Pérez and E. Arellanes. 2013. Análisis temporal de los hábitos alimentarios de la nutria neotropical (Lontra longicaudis) en el rio Zimatán en la costa de Oaxaca, México. Therya 4:311-326 
Calderón-Capote, M. C., A. V. Rojas-Rojas, C. Cárdenas-González And A, Pardo-Martínez. 2015. Familia Mustelidae. Pp. 110-135, in Los carnívoros terrestres y semiacuáticos continentales de Colombia: Guía de Campo (Suárez-Castro, A. F., and H. E. Ramírez-Chaves, eds.). Universidad Nacional de Colombia. Bogotá, Colombia.

Castro-Revelo, I., And G. Zapata-R í os. 2001. New altitudinal record for Lontra longicaudis (Carnivora: Mustelidae) in Ecuador. Mammalia 65:237-239.

Emmons, L. H., AND F. Feer. 1997. Neotropical rainforest mammals: a field guide. The University of Chicago Press. Chicago, U. S. A.

González-Maya, J. F., A. A., Cepeda, J. L., Belant, D. A., ZárrateCharry, S. A., Balaguera-Reina, and A., Rodríguez-Bolaños. 2011. Research priorities for the small carnivores of Colombia. Small Carnivore Conservation 44:7-13.

Guerrero-Flores, J. J., S., Macías-Sánchez, V., Mundo-Hernández, AND F. MÉndez-SÁnChez. 2013. Ecología de la nutria (Lontra longicaudis) en el municipio de Temascaltepec, Estado de México: estudio de caso. Therya 4:231-242.

Helder, J., AND H. Ker de Andrade. 1997. Food and feeding habits of the neotropical river otter Lontra longicaudis (Carnivora, Mustelidae). Mammalia 61:193-204.

LARIVIÈRE, S. 1999. Lontra longicaudis. Mammalian Species 609:1-5.

Martín-Torrijos, L., J. V. Sandoval-Sierra, J. Muñoz, J. DiéguezURIBEONDO, J. BosCh, AND J. M. Guayasamin. 2016. Rainbow trout (Oncorhynchus mykiss) threaten Andean amphibians. Neotropical Biodiversity 2:26-36.

MAYOR-Victoria, R., AND A. BOtero-Botero. 2010a. Dieta de la nutria neotropical Lontra longicaudis (Carnívora, Mustelidae) en el río Roble, Alto Cauca, Colombia. Acta Biológica Colombiana 15:237-244.

Mayor-Victoria, R., And A. Botero-Botero. 2010b. Uso del hábitat por la nutria neotropical Lontra longicaudis (Carnivora: Mustelidae) en la zona baja del río Roble, Alto Cauca, Colombia. Boletín Científico Centro Museos Historia Natural 14:121-130.

MonRoy-VILChIS, O., AND V. Mundo. 2009. Nicho trófico de la nutria neotropical (Lontra longicaudis) en un ambiente modificado, Temascaltepec, México. Revista Mexicana de Biodiversidad 80:801-806.

Noguera-Urbano, E. A. and S. Montenegro-Muñoz. 2011. Primer registro de la nutria tropical o lobito de río (Lontra longicaudis Olfers 1818) en el Piedemonte Andino-Amazónico y comentarios sobre la distribución en Putumayo Colombia. Novedades Colombiana 11:19-25.

Parrado-Sanabria, Y. A. 2012. Historia de la Acuicultura en Colombia. AquaTIC 37:60-77.

Ferrer-Pérez, A. F., M. B., Gutiérrez, and C. A., Lasso. 2009. Mamíferos de la Estrella Fluvial de Inírida: ríos Inírida, Guaviare, Atabapo y Orinoco (Colombia). Biota Colombiana 10:209-218.

Ramírez-Chaves, H. E., and E. A. Noguera-Urbano. 2010. Lista preliminar de los mamíferos (Mammalia: Theria) del departamento de Nariño, Colombia. Biota Colombiana 11:117-140.

Restrepo, C., and A. Botero-Botero. 2012. Ecología trófica de la nutria neotropical Lontra longicaudis (Carnivora, Mustelidae) en el río La Vieja, alto Cauca, Colombia. Boletín Científico del Museo de Historia Natural Universidad de Caldas 16:207-214.
Rojas-Díaz, V., M. Reyes-Gutierrez and M. S. Alberico. 2012 Mamíferos (Synapsida, Theria) del Valle del Cauca, Colombia. Biota Colombiana 13:99-116.

Solari, S., Y. Muñoz-Saba, J. V. Rodríguez-Mahecha, T. R. Defler, H.E. Ramírez- Chaves and F. Trujillo. 2013. Riqueza, endemismo y conservación de los mamíferos de Colombia. Mastozoología Neotropical 20:301-365.

Sunquist, M. E., AND F. C. SUnquist. 1989. Ecological constraints on predation by large felids. Pp. 283-301, in Carnivore behavior, ecology, and evolution (Gittleman J. L., eds.) Springer. Ithaca, U.S.A.

Trujillo, F., AND D. ARCILA. 2006. Nutria neotropical Lontra longicaudis. Pp: 249-254, in Libro rojo de los mamíferos de Colombia (Rodríguez-Mahecha, J. V., M. Alberico, F. Trujillo, and J. Jorgenson, eds.). Conservación Internacional Colombia, Ministerio de Ambiente, Vivienda y Desarrollo Territorial. Bogotá, Colombia.

Associated editor: Juan Pablo Gallo

Submitted: July 20, 2016; Reviewed: November 3, 2016;

Accepted: December 9, 2016; Published on line January 15, 2017. 